DOI: 10.20472/IAC.2019.049.003

\author{
ABDULA AZIZI \\ South East European University, Tetovo, Macedoina \\ LINDITA NEZIRI-CEKA \\ SEEU, Tetovo, Macedonia
}

\title{
THE SOCIAL CARE SYSTEM AND FINANCIAL IMPLICATIONS FOR CHILDREN WITHOUT PARENTAL CARE IN NORTH MACEDONIA
}

\begin{abstract}
:
Since children are an important part of any society, there should be no lack of institutions, mechanisms and activities responsible for building public policies for children without parental care. Positive laws in the North Macedonia have also included some of the international standards (reflected in relevant international conventions); and there is also a care system for children without parents; while there are also missing "symbolic" budgetary tools foreseen to develop activities in this area.
\end{abstract}

However, the Republic of Northern Macedonia, as well as other transition countries, continues to have problems in sound structuring of social policies in general and in particular faces difficulties with the care of children without parents.

This study aims through the analysis of official data to highlight the problems faced by children without parental care; the level of realization of children's rights in the respective institutions; and make recommendations regarding the improvement of the social care system.

Through an analysis of the fundamental problems faced by relevant institutions in the practical implementation of social services for children without parental care, I claim to encourage improvements in government policies for sound institutional, professional and financial support for a worthy human parental care treatment; as well as to provide the reader and the academic community with information on the current state of play in this sector of social care.

In this paper, statistical data have been analyzed by the State Statistical Office and interviews were conducted with the authorities of the institutions responsible for the care of children without parents. The methodology used in this study is: review of data from reports - statistics, documents, strategies, budget, positive laws review, and interviews with officials in the framework of care institutions.

It is concluded that current policies are not suitable for the proper treatment of children without parents, therefore a more proactive and inclusive approach is required from relevant political and institutional actors in this area.

\section{Keywords:}

Children, Parental Care, North Macedonia 


\section{Introduction}

When referring to the issue of children without parental care, it is necessary to start from the official data of the responsible international organizations, in order to have an overview of what extent this population is present. The Convention on the Rights of the Child (1989) recognizes them the right to love, care and protection from the family. While children who cannot grow up from their families, need an appropriate alternative environment, while institutional care remains to be used only as a last resort or temporary measure.

Unfortunately, millions of children around the world live in institutions, in formal or informal care, separated by their parents.

An inadequate childcare environment that is separate from their families, in emergency situations or armed conflict, may hinder the child's emotional and social development and leave the children extremely vulnerable to abuse and exploitation, including abuse sexual and physical violence. But even when they are placed in institutions or foster families, their wellbeing is often not adequately monitored. ${ }^{1}$

According to UNICEF data, around 153 million children worldwide are orphans. ${ }^{2}$ Every day, about 5.700 other children become orphans because of war, natural disaster, poverty, disease, stigma, and medical needs. ${ }^{3}$ The risk of increasing their numbers is represented by factors such as the impact of HIV / AIDS, armed conflict, disability, poverty and social deprivation. Most orphans are estimated to have registered countries such as India (31 million), China (20.6 million), Nigeria (12 million), Bangladesh (4.8 million), Ethiopia (4.8 million), Indonesia (4.8 million), Democratic Congo (4.2 million), Brazil (4.2 million), South Africa (3.7 million). ${ }^{4}$

The Republic of North Macedonia also faces the phenomenon of children without parental care, but not so large as the above-mentioned states. In this regard, there is no lack of support from UNICEF, which assisted the Macedonian government in establishing support services to prevent institutionalization of children. This included drafting a national strategy that was adopted by the government, developing a programme for registering children at risk and monitoring their development and status, a social mobilization campaign, and the opening of day-care centres for children with learning disabilities."

In the Republic of North Macedonia, the care of close relatives of children without parental care is realized in two possible ways:

in informal form based on inherited tradition, however, it is difficult to measure and evaluate data as there is a lack of official information from central and local institutions;

Institutional form is presented as institutional and formal protection (based on laws and other by-laws).

\footnotetext{
${ }^{1}$ Child Protection: Children without Parental Care, UNICEF p.1

2 https://www.sos-usa.org/our-impact/focus-areas/advocacy-movement-building/childrens-statistics

3 https://adoption.org/many-orphans-worldwide

4 https://www.quora.com/Which-countries-have-the-most-orphans-in-need-of-adoption

${ }^{5}$ lbid, p.2
} 
Generally, the formal care system for children without parental care consists of: adoption service; Care in "family homes"; Care through custody; Residential care of the institutional type; Day care centers for children with social problems; Family reunification services.

The Constitution of the Republic of North Macedonia ${ }^{1}$ and a whole set of laws guarantee the rights of children, especially Family law ${ }^{2}$, the Law on Children Protection ${ }^{3}$, the Law on Social Protection ${ }^{4}$ etc. Constitution of the Republic of North Macedonia (Amendments to the Constitution I-XXXII) ${ }^{5}$ in Article 40, paragraph 3 highlights: "The Republic provides special protection to children without parents and children without parental care".

Family Law in the article 12 mention "The Republic, through guardianship, provides protection of children without parents, juvenile children without parental care and adult persons under conditions and in a manner determined by this Law". The same law foresees the possibility of adoption (Article $104 \mathrm{gj}$ ), following the approval received by the Commission within the Center for Social Work for the suitability of the conditions and circumstances of the family / person who has expressed the wish for the adoption of the parentless child. Article 159 underlines that "Under custody will be placed, a minor without parental care". Whereas, the person without parental care defines it as well "A child whose parents are not alive who are missing, are unknown or have an uninhabited residence for more than one year and a child whose parents, regardless of the reasons, temporarily or permanently do not perform their parental rights and duties." Article 160 defines that "the custodian of the minor is obliged to take care of the personality of the minor, and in particular for the health, education and training for living and working independently". This obligation belongs to him until the person to whom he cares reaches the age of 18, adopted by the other person or marries, and after that the Center for Social Work should be cared for (Article 163).

\section{Institutional actors}

Within the institutional framework there are many institutions involved in the care of children without parental care, through various activities in their field of legal competencies, as follows:

- Ministry of Labor and Social Policy, creates policies and strategies for prevention and social protection. As responsible institutions within the ministry are the inter-municipal centers for social work and social protection institutions.

- $\quad$ The Institute for Social Activities as a research and development institution monitors and studies social phenomena; supervises work, social workers and other social service providers at the Center for Social Work.

- The Inter-municipal Centers of Public Institutions for Social Work. In North Macedonia, there are 30 inter-municipal social welfare centers, through which social protection is realized as

\footnotetext{
${ }^{6}$ Official Gazette of the Republic of Macedonia, No. 52/1991

${ }^{7}$ Official Gazette of the Republic of Macedonia, No. 153, 20.10.2014

${ }^{8}$ Official Gazette of the Republic of Macedonia, No.17, 29.12.2010

${ }^{9}$ Official Gazette of the Republic of Macedonia, No.79/2009

${ }^{10}$ Official Gazette of the Republic of Macedonia, Skopje, 2011
} 
a state-organized activity for preventing the fundamental social risks that the citizen and his family may face in life.

- Centers for Social Work (CSWs) as guardianship bodies supervise the exercise of parental rights; propose preventive measures; initiate procedures for the deprivation of the rights of parents and submit offenses to parents. CSW cooperate with the Ministry of Interior, the Public Prosecutor's Office and the courts. If the team of experts finds that the child is mistreated or the parents have not cared for their parental obligations, the CSW initiates a procedure for the revocation of the parental right and at the same time informs the Ministry of Interior. After the withdrawal of the parental right, the guardianship authority may hand over the child to the Homes for Orphans and Parental Care. CSWs engage in placement of children under guardianship; placement in a foster family; inclusion of children in educational institutions (through notification to the State Educational Inspectorate) and provision of health care through notification of the local health care center.

- The Ministry of Internal Affairs is a state administrative body competent for the performance of: protection of life, personal security and property of the people; protection of the freedoms and rights of individuals and citizens guaranteed by the Constitution; prevention of commission of offenses and offenses; detecting and detaining offenders and transferring them to the competent authorities, etc.

- The Ministry of Education and Science is responsible for the educational process, ie the inclusion of all children (children without parental care, abandoned, homeless children) in educational institutions. Like all other children, children without parental care and children without parents are subject to the Law on Compulsory Primary and Secondary Education. The Ministry of Education and Science offers free books; in cooperation with other organizations and donors, provides scholarships for children; follows their regularity at school.

- Ministry of Health - Given that children often do not have health insurance, the Government through the Ministry of Health through the Health Insurance Program provides them with health protection.

- Ministry of Justice - As of 1 January 2010, the Registry Office (as a body within the Ministry of Justice) has the responsibility to keep records of births, marriages and deaths, protects and preserves them; issues birth certificates and other similar certificates.

- The Ministry of Local Self-Government and the municipalities cooperate with all relevant institutions and support the programs and activities of the institutions; informs the Minister of Labor and Social Policy if they are children on the street in their territory (children without parental care or abandoned children). 


\section{The official data}

Below, within the two tables are provided official information on the number of children without parental care; their age; education; who have been sheltered for care in the respective institutions; the number of employees in those institutions; their qualification etc.

TABLE 1: Beneficiaries of institutions for housing children without parents and parental care

\begin{tabular}{|c|c|c|c|c|}
\hline Year / User & Total & $\begin{array}{c}\text { Institutions } \\
\text { for } \\
\text { newborns }\end{array}$ & $\begin{array}{l}\text { Institutions } \\
\text { for } \\
\text { children }\end{array}$ & $\begin{array}{l}\text { Livelihood } \\
\text { Institutions }\end{array}$ \\
\hline \multirow[t]{2}{*}{2016} & 146 & 66 & 52 & 28 \\
\hline & $\begin{array}{c}\text { Females } \\
64\end{array}$ & 28 & 20 & 16 \\
\hline \multirow[t]{2}{*}{2017} & 134 & 65 & 41 & 18 \\
\hline & $\begin{array}{c}\text { Females } \\
63\end{array}$ & 32 & 13 & 18 \\
\hline Age $0-3$ years & 62 & 62 & - & - \\
\hline 3-6 years & 7 & 3 & 4 & \\
\hline $7-10$ years & 14 & - & 14 & - \\
\hline 11-14 years & 8 & - & 8 & - \\
\hline $15-18$ years & 42 & - & 14 & 18 \\
\hline Over 18 years & 1 & - & 1 & - \\
\hline Parents' customers & 134 & 65 & 41 & 28 \\
\hline No parents & 16 & - & 5 & 11 \\
\hline Only with the mother & 72 & 54 & 14 & 4 \\
\hline Only with dad & 17 & 1 & 5 & 11 \\
\hline With two divorced parents & 19 & - & 17 & 2 \\
\hline $\begin{array}{l}\text { Customers according to payment of } \\
\text { stay }\end{array}$ & 134 & 65 & 41 & 28 \\
\hline Pay completely & - & - & - & - \\
\hline Pay in part & - & 3 & - & - \\
\hline They do not pay & 131 & 62 & 41 & 28 \\
\hline Users by education & 134 & 65 & 41 & 28 \\
\hline Primary education & 24 & - & 24 & - \\
\hline Secondary education & 43 & - & 15 & 28 \\
\hline Faculty education & - & - & - & - \\
\hline They did not go to school & 67 & 65 & 2 & - \\
\hline
\end{tabular}

Source: Social protection for children, State statistical office, Statistical review, 2.4.18.10/901, p. 25

Regarding the data from Table 1, the number of children from the age of up to 3 years old, who are housed in the respective institutions, account for almost half the number of people without parental care. Usually, they are children who do not have a father (no one knows who he is) but have only a mother; but there are such children who do not have any parents (they are 
unknown), have only a father or a divorced parent. The age of their care is usually up to 18 years, though there are exceptions.

What is to worry about the official data is why half of these children do not attend school?

TABLE 2: Employed in institutions for placement of children without parents and parental care

\begin{tabular}{|c|c|c|c|c|}
\hline & Total & $\begin{array}{l}\text { Institutions } \\
\text { for newborns }\end{array}$ & $\begin{array}{l}\text { Institutions } \\
\text { for children }\end{array}$ & $\begin{array}{l}\text { Livelihood } \\
\text { Institutions }\end{array}$ \\
\hline \multirow[b]{2}{*}{2016} & 153 & 57 & 42 & 54 \\
\hline & $\begin{array}{c}\text { Females } \\
124\end{array}$ & 52 & 30 & 42 \\
\hline \multirow[b]{2}{*}{2017} & 148 & 57 & 38 & 52 \\
\hline & $\begin{array}{c}\text { Females } \\
122\end{array}$ & 53 & 28 & 41 \\
\hline \multicolumn{5}{|l|}{ Employed by profession } \\
\hline Psychologist & 5 & - & 1 & 4 \\
\hline Pedagogue & 11 & 1 & - & 10 \\
\hline Sociologist & 4 & 1 & 1 & 2 \\
\hline Doctor & 1 & 1 & - & - \\
\hline Defectologists & 2 & 1 & - & 1 \\
\hline Health worker & 35 & 34 & 1 & - \\
\hline Lawyer & 3 & 2 & 1 & - \\
\hline Economist & 4 & 1 & 1 & 2 \\
\hline Others & 82 & 17 & 33 & 32 \\
\hline \multicolumn{5}{|c|}{ Employed by education level } \\
\hline Higher education & 50 & 7 & 18 & 25 \\
\hline Professional education & - & - & - & - \\
\hline Pre-university education & 2 & 2 & - & - \\
\hline High school education & 78 & 39 & 14 & 25 \\
\hline Elementary School & 18 & 9 & 7 & 2 \\
\hline
\end{tabular}

Source: Zastita na Deca, Mladi i Vosrasni, State Statistical Office, Statistical overview 2017, p. 26

Regarding the data from Table 2, the largest number of employees in the care institutions of children without parents are women, with secondary school graduated. What is apparent from the data is that there is no staff as a social worker, while the number of other persons employed by more than half are unskilled to exercise this type of activity.

\section{$4 \quad$ Forecasts from politics}

In 2018, the Government of the Republic of North Macedonia approved the Program for Construction, Supply and Maintenance of Child Protection Facilities, which provided for an amount of 41,600 denars from the budget, for the maintenance of facilities in Valandovo, Sveti 
Nikole, Probistip, Bitola, Kavadarci etc.; municipalities mostly inhabited by the Macedonian community.

Once financial aid and help in kind - this right can be for individuals or families who find themselves in social risk ... as well as children or young people without parents or parental care after leaving the institution or family caring. To this end, in 2018, 26.000.000 denars are foreseen. ${ }^{1}$ In favour of the right to housing assistance for a person without parental care until the age of 18 , or after the termination of custody, mainly at the age of 26 , in the Budget for 2018 were foreseen 1.600 .000 denars. $^{2}$ Financial assistance for a person below the age of 18 has had the status of a child without parental care up to the age of 26 , providing additional assistance to individuals who are enrolled in the first academic year of the first, second and third cycle - studies of doctoral studies as full-time students in public higher education institutions. In 2018, the total number of these users is estimated to be around 180 people. For this purpose, in the budget for 2018 were foreseen 47.000 .000 denars. $^{3}$ Accommodation in student dormitories or other institutions of children without parents and parental care for qualification for life and selfemployment at least until completion of secondary education if there is no opportunity to provide care and education in another way; for which the Center for Social Work will assess that the institution can provide child custody, education and development. To this end, in the budget for 2018, 1.600.000 denars were planned. ${ }^{4}$

Based on the Law on Child Protection, the Government of the Republic of North Macedonia attempts to develop and advance the child protection system through the Program for the Development of Child Protection Activities for $2019^{5}$ and the 2019 Budget.

Through this program, there is a tendency to provide conditions for inclusion of children in the protection system from pre-school age, use of space and personnel resources, and creation of conditions and other forms of child education.

Thus, activities should be directed towards:

- Completion of the decentralization process of child protection activities in cooperation with municipalities, support for the child;

- Establishment of new institutions;

- Improving social services and financial support.

\footnotetext{
${ }^{11}$ Pursuant to Article 4, paragraph 2 of the Law on Social Protection ("Official Gazette of the Republic of Macedonia" No. 79/09) and Article 33 of the Law on Execution of the Budget of the Republic of Macedonia for 2018 ("Official Gazette of the Republic No. 196/17), the Government of the Republic of Macedonia, at its session held on 22 January 2018, adopted the "SOCIAL PROTECTION PROGRAM FOR 2018" Official Gazette of the Republic of Macedonia, no. 13 and 22 January 2018, pp.8-9

12 lbid, p.8

${ }^{13}$ Ibid, p.8

${ }^{14}$ lbid, p.9

${ }^{15}$ Official Gazette of the Republic of Macedonia, No.246, 28.12.2018
} 
The social protection of children without parents and parental care as well as for children at risk will be harmonized in order to respect the standards for social integration in society and the respect of the rights of children laid down in the UN Convention on the Rights of the Child. In this regard, the capacities of professionals in the social protection institutions will be strengthened and the network of foster families will be developed, in particular the establishment of specialized care families. ${ }^{1}$

For 2019, within the Ministry of Labor and Social Policy, budget funds are foreseen in the amount of 44.610 .701 denars. Part B mentions measures to reduce poverty; employment of children without parental care ${ }^{2}$; whereas Voice 3 provides support for child protection institutions; construction, supply and maintenance of child protection facilities. ${ }^{3}$

\section{$5 \quad$ Expectations from politics}

For children without parental care, placed in care institutions, some fundamental rights should be considered, such as:

- $\quad$ Children can be accommodated in these institutions only if this is a choice that meets their requirements according to an assessment by the responsible authorities;

- $\quad$ Placement in these institutions should not be long-term;

- Children without parental care should have regular contact with their families (sister, brother);

- $\quad$ Their dignity must be respected;

- $\quad$ Respect for their ethnic, religious and linguistic background;

- $\quad$ Their right to privacy must be respected;

- $\quad$ Their right to health care should be respected;

- $\quad$ They should have equal opportunities for education, vocational training etc. ${ }^{4}$

In this regard, expectations from an institutional care should result in: the appropriateness of the service; individual care plan; nutrition; appearance; clothing; material needs; providing physical, mental and emotional health; education and entertainment; protection against abuse; accommodation; independent living. In this social category in need, it is important to ensure

\footnotetext{
${ }^{16}$ The Government of the Republic of Macedonia, at the session held on the date December 28, 2018, has approved "Social Protection Program for 2019", Official Gazette of the Republic of Macedonia, No.246, 28 December 2018, p.5

17 Ibid, p.14

18 lbid, p.270

${ }^{19}$ All of these rights derive from the 2015 Council of Europe Committee of Ministers' recommendations on the right of children living in institutions.
} 
rigorous and accurate compliance with the above expectations.

\section{$6 \quad$ Interview with institutional actor}

From the discussions conducted and the interview ${ }^{1}$ within this study, we find some of the main causes of the phenomenon of children without parental care:

- $\quad$ Social and economic problems within the family;

- $\quad$ Parents' divorces and the disagreement of no one hold the child;

- $\quad$ Parents' death or financial inability to hold children from the other parent;

- $\quad$ Unemployment and other economic difficulties to care for the child;

- $\quad$ Lack of housing;

- Domestic violence;

- $\quad$ Child's physical or mental disability;

- $\quad$ Early pregnancy of girls who cannot cover childbirth costs or due to traditional prejudices.

\begin{tabular}{|l|c|}
\hline \multicolumn{1}{|c|}{ Question } & $\begin{array}{c}\text { Mark } \\
\text { from } \\
\mathbf{0} \mathbf{~ - ~ 1 0 ~}\end{array}$ \\
\hline $\begin{array}{l}\text { How much do the children's parents care about the fate of sheltered children in your } \\
\text { institution? }\end{array}$ & 2 \\
\hline How much does your institution meet the basic conditions for caring for a parentless child? & 7 \\
\hline Do you consider that the state allocates sufficient funding for caring for a parentless child? & 5 \\
\hline Infrastructure conditions in your institution are suitable for care? & 5 \\
\hline Do you think the funds from the 2019 budget dedicated to your institution are sufficient? & 6 \\
\hline
\end{tabular}

\footnotetext{
${ }^{20}$ The interview was conducted at "Detski Dom 11 Oktomvri"- Skopje, on 21.01.2019. Open questions were raised about the causes of this phenomenon, while closed questions where the interviewee has chosen the individual assessment scale on the questions asked.
} 
The data from the interviews doesn't look very promising:

- $\quad$ There is a low level of parents' interest in their children placed in care institutions;

- Working conditions in these institutions aren't satisfactory and infrastructure, technical and professional staffs are required;

- $\quad$ The financial resources allocated by the state budget are insufficient to ensure normal flow of work.

\section{Conclusion}

Being one of the poorest countries in Europe, the Republic of North Macedonia has limited opportunities to properly support social categories in need. In this respect, social protection policies are not developed as well. The social support currently offered is a minimum aid, which doesn't meet the basic requirements for its beneficiaries.

Moreover, from the data of the State Statistical Office (which are part of the work in Tables 1 and 2), it is evident that the lack of qualified staff in the care centers for children without parents.

From the above data we can conclude that:

- $\quad$ There is a lack of qualified staff at care centers for children without parents;

- There is a lack of institutions in the various regions of the state (especially in the western part of the country), or there is a regional disproportion to involving the state in the care for parental care;

- $\quad$ The state does not allocate sufficient means to cover the proper care activities for children without parental care;

- $\quad$ Parental care institutions cannot properly carry out their primary mission, inter alia due to the lack of infrastructure conditions;

- Institutions for the care of children without parental care do not have the necessary conditions of action and care.

There are several suggestions that should be taken:

- $\quad$ The state should take concrete steps to change the existing institutional structure, increase the number of staff and their professionalism, and open new institutions in countries where there are no such institutions, while in real need such as in the western region of the state;

- $\quad$ To increase control over the care institutions for solving practical problems; 
- $\quad$ The transition period for transferring the child from institutional care to an independent life should be facilitated through concrete measures;

- $\quad$ As a form of support for children without parental care, a scholarship and cover for tuition costs should be provided, vocational training;

- $\quad$ An independent state monitoring mechanism for children outside parental care needs to be established.

\section{References}

Analysis of fostering families in Macedonia, Institute for Social Work, Skopje, May 2018

Constitution of the Republic of Macedonia, Official Gazette of the Republic of Macedonia, No. 52/1991

Family law (previous text), Published in Official Gazette of the Republic of Macedonia, No. 153, 20.10.2014

Law on Child Protection, Official Gazette of the Republic of Macedonia, No.17 29.12.2010

Law on Social Protection, Official Gazette of the Republic of Macedonia, No.79/2009

Program for development of child protection activities for 2019, Government of Macedonia, Official Gazette of the Republic of Macedonia, No.246, 28.12.2018

Social Protection for Children, State Statistical Office, 2018 